\title{
Direct Writing Activity: A Strategy in Expanding Narrative Writing Skills for Elementary Schools
}

\author{
M. Habibi ${ }^{1,2, *}$, Sukirno ${ }^{1}$, Taufina ${ }^{2}$, Elfia Sukma ${ }^{2}$, Ari Suriani ${ }^{2}$, Rafhi Febryan Putera ${ }^{2}$ \\ ${ }^{1}$ Department of Primary Education Doctoral Program, Universitas Negeri Yogyakarta, Indonesia \\ ${ }^{2}$ Department of Elementary School Teacher Education, Universitas Negeri Padang, Indonesia
}

Received April 28, 2020; Revised August 15, 2020; Accepted August 28, 2020

\section{Cite This Paper in the following Citation Styles}

(a): [1] M. Habibi, Sukirno, Taufina, Elfia Sukma, Ari Suriani, Rafhi Febryan Putera, "Direct Writing Activity: A Strategy in Expanding Narrative Writing Skills for Elementary Schools," Universal Journal of Educational Research, Vol. 8, No. 10, pp. 4374-4383, 2020. DOI: 10.13189/ujer.2020.081003.

(b): M. Habibi, Sukirno, Taufina, Elfia Sukma, Ari Suriani, Rafhi Febryan Putera (2020). Direct Writing Activity: A Strategy in Expanding Narrative Writing Skills for Elementary Schools. Universal Journal of Educational Research, 8(10), 4374-4383. DOI: 10.13189/ujer.2020.081003.

Copyright $\bigcirc 2020$ by authors, all rights reserved. Authors agree that this article remains permanently open access under the terms of the Creative Commons Attribution License 4.0 International License

\begin{abstract}
Narrative writing learning material in the fourth grade thematic books Curriculum 2013 in Indonesia does not have appropriate writing steps. This causes the learning process to write narrative texts is not carried out properly. Therefore a solution is proposed by developing narrative writing teaching materials based on direct writing activity strategy. This type of study is Research and Development using the ADDIE model. The research data consisted of validity data, practicality data, and effectivity data. The result showed that the validity score of teaching material was 3.79 by category highly valid. The learning process of narrative writing had a score of 3.63 by category very good. The student response score for teaching material was 3.81, while the teacher's response score was 3.78. The mean of the experimental class learning outcomes was 85.27, while the mean of the control class learning outcomes was only 72.64 . The statistical test proved a significant difference in the teaching material for narrative writing developed. Based on these results, it can be concluded that the teaching material for narrative writing using direct writing activity is valid, practical, and effective to use.
\end{abstract}

Keywords Teaching Material, Narrative Writing, Direct Writing Activity

\section{Introduction}

Writing competence is one of the Indonesian language competencies supported in elementary schools. In the hierarchy of speaking skills, writing skills are at the highest level [1], [2], which means that writing skills can be only mastered by students if they have had listening, speaking and reading skills. This expertise proves that writing skills are the most difficult skills to master compared to speaking skills [3]. Those opinions were not without reason, writing skills are the most complicated skills that require mastery of various linguistic elements such as grammar, vocabulary, punctuation, and spelling [4]-[6].

The most common type of writing skills found in reading text in elementary schools is writing narrative text [2], [7], [8]. Therefore, many opinions say that writing skills can be improved by improving the narrative text writing skills [9]-[11]. Narrative text is defined as a type of text that aims to tell an event to entertain the reader and has moral values in the story [12], [13]. The hallmark of narrative texts is that they have a structured organizational structure including orientation, complications, and resolution [14].

As a part of writing skills, narrative writing also includes skills that are difficult for students to master [3]. There are many obstacles for students in mastering these skills including the ability of teachers to teach, student interest in learning, learning strategies or methods, teaching materials, learning environments, and duration of teaching writing [8], [15]. Several studies have shown that the use of learning strategies or methods is the most influential factor. Grenner's research shows that the use of observation method can improve students' skills in writing primary school class narratives in Sweden [13]. However, 
according to Slamet, the use of teaching material also has a big influence because it can provide support in writing process. Teaching material is a student worksheet, so the use of appropriate teaching material can improve students' skills particularly in narrative writing [16]. Based on this opinion, it can be concluded that the use of teaching material that adopts writing learning strategies/methods is the most appropriate solution in improving students' skills in narrative writing.

In reality, the learning material for writing narrative texts contained in the fourth grade thematic books of the Curriculum 2013 has not adopted an appropriate writing strategy/method [17]. Writing material is only in the form of instructions which assign students to write experiences when playing at home environment and when participating in competitions. Writing learning is focused only on results, students are not directed to carry out writing activities step by step. Research on narrative writing in elementary schools conducted by Nurjani \& Zulela et al shows that learning material for writing stories contained in student books is presented monotonously. Writing learning is carried out directly on content without pre-writing activities such as formulating writing ideas and making essays and post-writing activities such as checking punctuation, grammar, spelling, and publishing activities [18], [19]. Kamariah et al \& Masood through their research concluded that the lack of teaching materials and writing activities that are straight on content causes students' difficulty in determining the topic so that they experience confusion at the beginning and the end of writing[20], [21].

Based on the above problems, it is necessary to develop teaching material for narrative writing as a companion to the 2013 curriculum thematic books in teaching students narrative writing skills. The right type of writing learning strategy to collaborate with this narrative writing teaching material is the direct writing activity strategy. According to Blake and Spennato, a direct writing activity strategy is a strategy to develop writing skills using a writing process approach [22]. This strategy focuses on the process of guiding student activities directly [7]. The direct writing activity strategy applies the writing steps systematically including prewriting, drafting, revising, editing, and publishing stages.

The procedures of writing activities using the direct writing activity strategy according to Crawley \& Lee Mountain [23] and Eanes [22] are: (1) preparing students to write by helping them choose topics that are not too general or too narrow, (2) helping students make writing frames through formulating question activities related to the topic chosen, (3) guiding students to write the first draft using information that has been collected, (4) each student reads a draft that has been written to a partner or teacher, (5) students provide suggestions to friends' draft related to the use of vocabulary, punctuation marks, and spelling, (6) students re-edit their writing according to the revised results of the pair, (7) students publish their writing in front of class or in classroom wall magazine. Direct writing activity strategy is very effective in developing narrative writing teaching material. Research conducted by Rietdijk shows that the use of direct writing activity strategy makes students better in understanding the correct writing rules because there are feedback activities continued by revising the writing [24].

\section{Literature Review}

\subsection{Teaching Material: Role of Teaching}

There are many factors influencing the effectiveness of learning, but the use of teaching materials is slightly more influential because it guides students throughout the learning process, provides greater support, and plays a central role in teaching and learning [25]. In fact, according to Garton \& Grapes "Materials are fundamental to language learning and teaching (...) but materials cannot be viewed independently of their users"[26].

Teaching material can be interpreted as a set of tools that contain information needed by teachers in planning and implementing learning [27], [28]. If interpreted from the word composer, the teaching material has meaning as the material used by educators to teach. More broadly, teaching material can be defined as any form of resources that can be utilized by teacher to assist him/her in carrying out teaching and learning activities together with students in class [29], [30]. Based on these definitions, according to Ahmar \& Rahman teaching materials can be in the form of written or unwritten material [31].

Teaching material has a fundamental function in directing the learning process [32]. The direction and purpose of learning can be predicted through the content of the teaching materials used. Good or not the contents of a teaching material can affect the quality of learning and learning outcomes to be achieved by students [29]. At least, teaching material has a function that cannot be underestimated, namely: (1) as a guide for teachers to direct all activities in the learning process, (2) a substance of competence that should be taught to students [31], (3) as a guide in following all learning process activities, (4) the substance of competencies that students must learn and master [33], (5) as an evaluation tool for achievement and mastery of learning outcomes [25].

\subsection{Narrative Writing}

Writing is an active productive activity, because in writing activities the writer is directly involved in producing various information that can be utilized by community[6], [34]. Writing skill is one of the competencies in learning Indonesian in elementary schools. The most common type of writing skill taught and the most problematic for elementary school students is narrative 
writing [24].

Narration has meaning as "telling". It is a text that tries to tell an event in the order in which it occurred [35]. Narration can also be said as a text that seeks to present a series of events through four series of events namely orientation, climax, anti-climax, and resolution with the intention of giving meaning to an event so that the reader can take the wisdom of the story [17].

The narrative text has characteristics that distinguish it from other text types. It is structured by several components, namely themes, actions or actions, characters, settings, plot, character, and point of view [2]. The most important element in narrative text is the action or action of the character because the element is the thing that is told in the story and acts as a storyline [36]. Based on the constituent components, the narrative text aims to narrate an event so that the reader seems to see the event being told.

Tarigan explained the purpose of learning to write narrative text in elementary school is that students are able to re-express their experiences through coherent stories using written language symbols [2]. Why should it be based on experience? According to Janne et al [37], the fourth grade students are still in the stage of concrete operational development. It means that the new students can write down things that they have seen or experienced. Learning to write stories that are fictional and delusional can only be taught when students are aged 11-12 years or before the formal operational period.

\subsection{Direct Writing Activity Strategy}

Direct writing activity strategy is a writing strategy that involves students in the writing process directly [38]. According to Syafii, in using the direct writing activity strategy the teacher not only guides students to the writing task but also provides modeling for each writing phase considering that elementary school students have never done narrative writing activities before [39].

The use of direct writing activity strategy accustoms students to write in accordance with the steps of writing good and right. Students will participate in writing activities directly through systematic steps [40]. Blake and Spennato explain some advantages of direct writing activity strategy, namely: (1) this strategy can be applied in learning to write at all levels of education, (2) this strategy uses an approach in its application, so students will practice writing properly according to established procedures, (3) it can be applied in all types of composing learning, (4) it makes learning to write more meaningful and has value [22].

In creating an interesting and structured writing learning process, a direct writing activity strategy has several systematic steps, namely: (1) Prewriting. Prepare students to write. Help them choose and narrow writing topics and help students identify the sources of information. (2)
Framing the writing assignment. Encourage students to formulate questions that are relevant to their topic and will look for answers. (3) Writing the assignment. Students organize their information into the draft, add desired information to answer the questions in framing activities. (4) Revising the draft. Furthermore, the author read his paper to other students or teachers. Students or teachers to make suggestions that will help the students to explain their thinking then use the suggestions from students or teachers. (5) Editing. Each student must have a paper editing. The editing was made to the symbols contained in the writings. (6) Final draft. Students can publish their writings to read by students or teachers[23].

\section{Methods}

This study is Research and Development adopting the ADDIE model to produce narrative writing teaching material based on direct writing activity strategies for the fourth grade elementary school students. Research and Development needs to be applied in the world of education. According to Borg \& Gall, research and development only plays a small role in education so far. Less than one percent of education expenditure is on this. Perhaps this is one reason why the progress of education is far behind other sectors [41].

ADDIE is an acronym for Analysis, Design, Development, Implementation, and Evaluation. This acronym is as well as a stage in this development process [42]. Pribadi explains the ADDIE stages as follows [43]: The analysis stage serves as a starting point for research aimed at finding out the situation of the problem before designing teaching materials. In the design phase, the researchers began to design the teaching materials based on the results of the analysis and direct writing activity strategy steps. At the development phase, several activities were carried out, namely developing an instrument to evaluate the teaching materials and testing the validity of the teaching materials. The implementation phase is the activity of continuous modification or revision to ensure the level of effectiveness and practicality of the developed teaching material. Evaluation activities are divided into two types namely formative and summative evaluation. Formative evaluation is related to the assessment at the development and implementation phase which leads to revision activities. Meanwhile, summative evaluation is the final conclusion of teaching material developed based on the results of validity, practicality, and effectiveness[42], [44].

The research sample was the fourth grade students in several elementary schools in Bukittinggi Indonesia in the 2017/2018 school year. The first trial activity involved 22 students, while the second one involved 48 students divided into experimental and control classes. Sampling for the experimental class and the control class used a simple 
random sampling technique, namely taking random sample members without regard to the strata in the sample population. Therefore, the researchers were free to choose the class taken as an experimental class and a control class [45], [46]. The experimental class was given treatment using narrative writing teaching materials based on the direct writing activity strategy. The control class was not given treatment, meaning this class only used the commonly used teaching materials, namely the 2013 Curriculum thematic student book.

Research data were collected through interviews, observations, questionnaires (questionnaires), and assessments of student writing. The interview aims to find out the opinions of teachers and students after using the teaching material developed. Observations were carried out to observe the activities of teachers and students during the learning process of narrative writing. Meanwhile, the questionnaire was used to assess the level of validity and practicality of teaching materials developed. The results of students' narrative writing both in the experimental class and the control class were useful to determine the level of effectiveness of narrative writing teaching material based on direct writing activity strategy.

The analysis of student learning outcomes in narrative writing was carried out with a non equivalent group pretest-posttest design technique, using pre-test and post-test results as an evaluation tool to compare the learning outcomes of experimental and control classes. Data calculations used the t-test, namely independent simples $t$-test through the SPSS 26 program, this test was used to determine whether there is a difference in the treatment given to a group of research subjects [47].

\section{Finding and Discussion}

Discussion of the result of this study is based on the stages of the ADDIE model and the types of data in development research which are data validity, practicality, and effectiveness.

\subsection{Need Analysis}

The analysis is interpreted as an attempt to investigate something to find out the real situation [20]. The need analysis in this research is an activity to investigate the things that should be applied in learning to write narration, including efforts to formulate the things needed in developing narrative writing teaching material [28].

The need analysis phase produces several concepts, first: the learning material for narrative writing must be structured according to the writing phase, the characteristics of narrative text, and the direct writing activity strategy step. Therefore, in the initial phase of learning, students are guided to choose the topic of writing, then determine the title of the writing, present the main points of the story in the form of webbing, and create a writing framework. In the next phase, there is material about developing writing frameworks into narrative text. Then in the final phase, material about revising and editing narrative text that has been produced by students is presented.

Second, teaching materials need to be supplemented with explanatory information/ instructions that are supported by examples. The explanatory information includes: (1) points that must be considered in writing, including the use of capital letters, choice of words, preparation of sentences, and the correct spelling, (2) instructions to register the main point of the story in the form of webbing, (3) instructions to make writing framework based on webbing, (4) instructions on how to develop the writing framework into narrative text, (5) instructions on how to revise and edit writing.

Third, the teaching material developed must be equipped with writing assignments. Teaching material functions as student worksheets. Narrative writing activities are not knowledge but skills. Therefore students need to hone their skills by doing various writing assignments [16].

Fourth, the display of teaching materials was adjusted to the characteristics of the fourth grade elementary school students. The development of teaching material was intended for students, then the teaching material must be attractive to the users. The teaching material was structured and easy for students to understand. The presentation of the material was done in a communicative and interactive language so that students feel happy and interested in learning. The use of color and layout must also be considered so that the impression of interesting teaching materials can be obtained [29].

\subsection{Design}

Based on the background of the problem and the result of the need analysis, the researchers developed the narrative writing teaching material as a solution to the problem of learning to write narrative text in elementary school. Teaching material developed has a structured material design according to the steps of writing and narrative text characteristics. Besides, teaching material also adopts one of the appropriate writing learning strategies, namely the direct writing activity strategy. The teaching material has also been equipped with various instructions that can help students in writing narrative texts. These instructions allow students to carry out writing activities independently [48]. The design of teaching materials, the use of colours, the illustrations, and the layout were also adapted to the characteristics of elementary school students, namely loving something interesting, interested in pictures, interested in communicative and interactive language, interested in bright colours, and interested in short sentences. The components of the developed teaching material consist of: (1) instructions on how to use of the teaching material, (2) learning indicators, (3) learning outcomes, (4) concept maps, (5) material explanations, (6) learning 1, (7) learning 
2 , and (8) learning 3 . The components of teaching materials can be seen in Figure 1.

The instructions to the use of teaching material are divided into two kinds, namely instructions for teachers and instructions for students. This guide serves as a general guideline in using teaching materials both by the teacher and students. Learning indicators are the minimum competencies that students must master after participating in narrative writing learning using teaching materials that are developed. This competency consists of several types and is a set of abilities that students must acquire in writing narrative text. Learning outcomes are the results that are expected to be achieved by students after participating in narrative writing learning. Learning outcomes not only focus on results but also on the writing process. Actually, they are a specific translation of the learning indicators, in learning outcomes the techniques or methods used to achieve each learning indicator are explained.

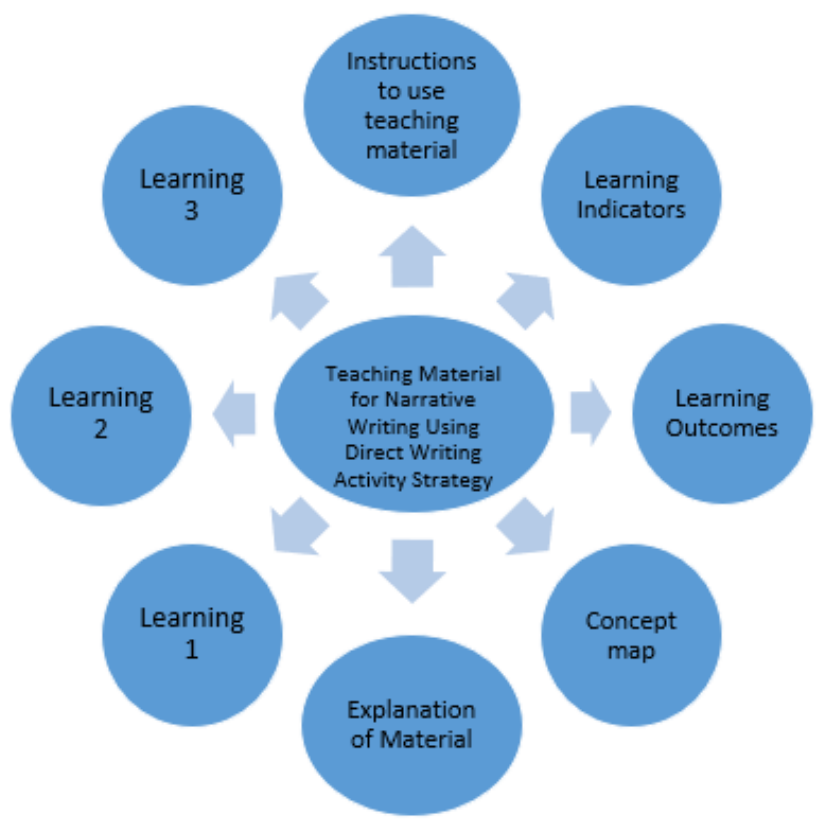

Figure 1. Components of teaching materials

Concept maps is a mapping of narrative writing steps which are grouped into three steps of writing, namely pre-writing, whilst-writing, and post-writing. These narrative writing learning steps were adjusted to the stages of direct writing activity strategy and explicitly describe the expected learning outcomes. The concept of map design can be seen in figure 2. Explanation of material is an explanation of the concepts that students must know in writing narrative text. These concepts include the definition of narrative text, the characteristics of narrative text, and components of narrative text, as well as the things that must be considered in writing including word selection, spelling, punctuation, and capital letters.. Learning 1, Learning 2, Learning 3 is a description of narrative writing learning material divided into three chapters. In each of these learning activities, students are guided to carry out the narrative writing activities with different topics.

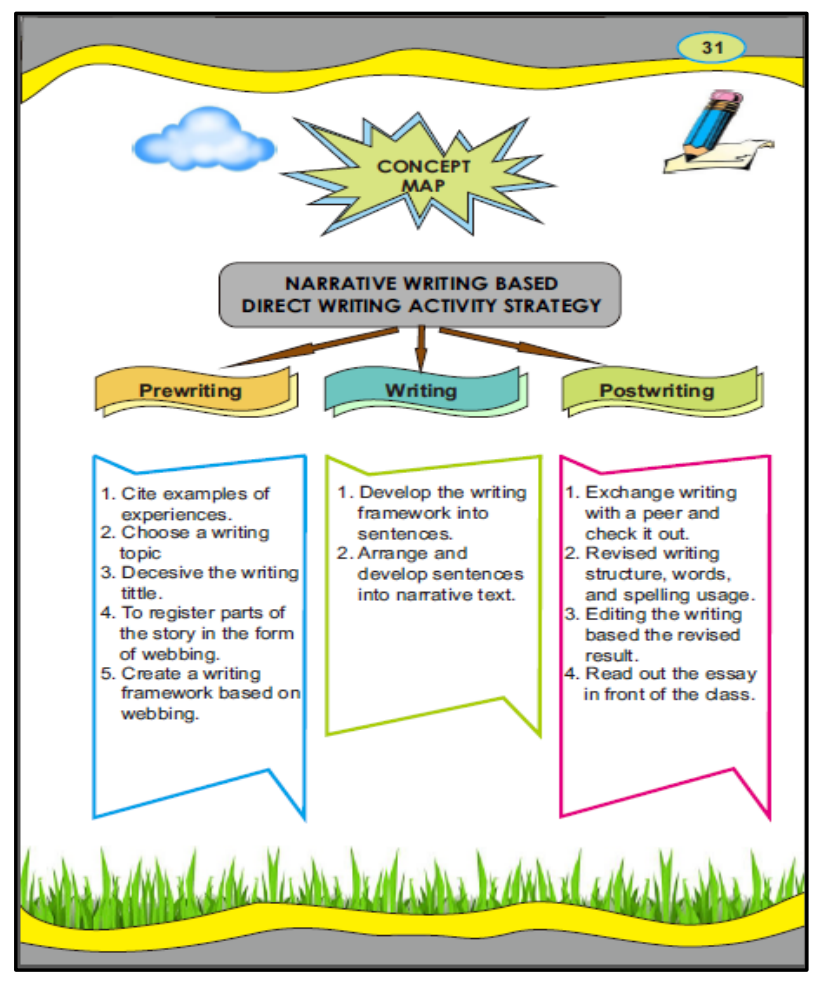

Figure 2. Design of concept maps

The material description of each lesson was structured according to the steps of the direct writing activity strategy. In each lesson, there is also a writing assignment that should be completed by students in order to be able to produce story text according to the chosen topic. Examples of student writing assignments can be seen in Figures 3, 4, and 5 .

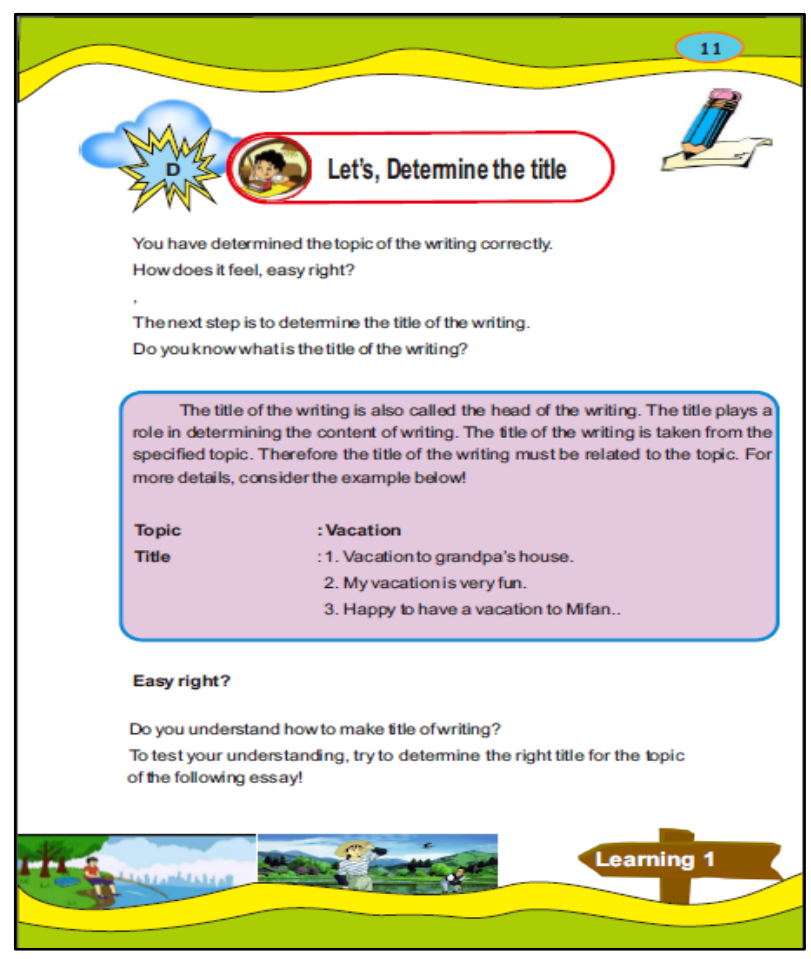

Figure 3. Determine the title of the writing 


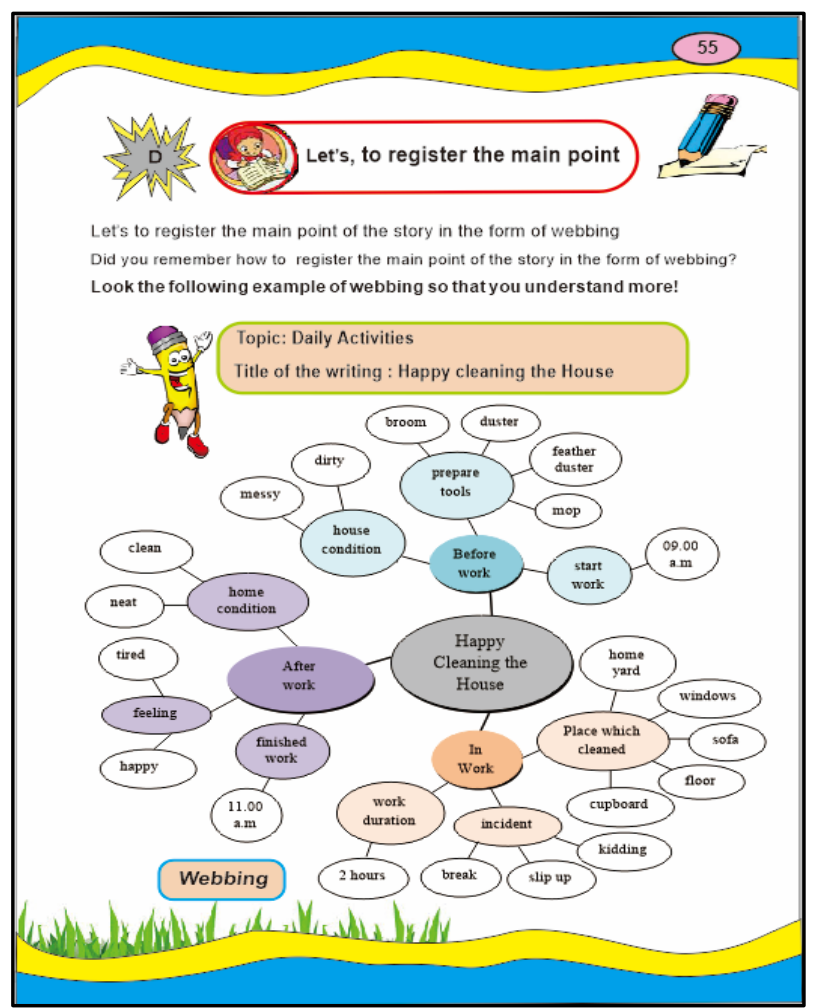

Figure 4. Design of webbing

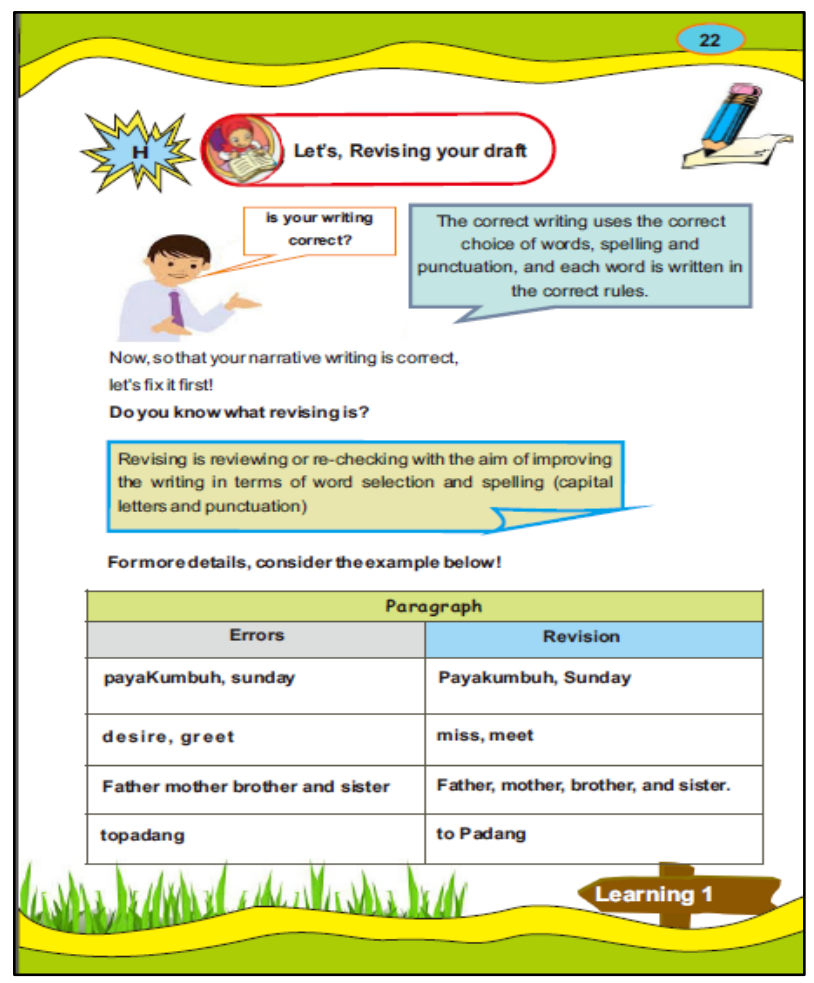

Figure 5. Design of revising the draft
The teaching material cover is designed with the light blue and light green main back ground. Light blue symbolizes peace while light green symbolizes naturalness. On the cover, there is a picture of children playing in the park. Playing is an activity that is most often done by children. Of course, this is in line with the theme of the development of teaching material. The cover design of teaching material can be seen in Figure 6

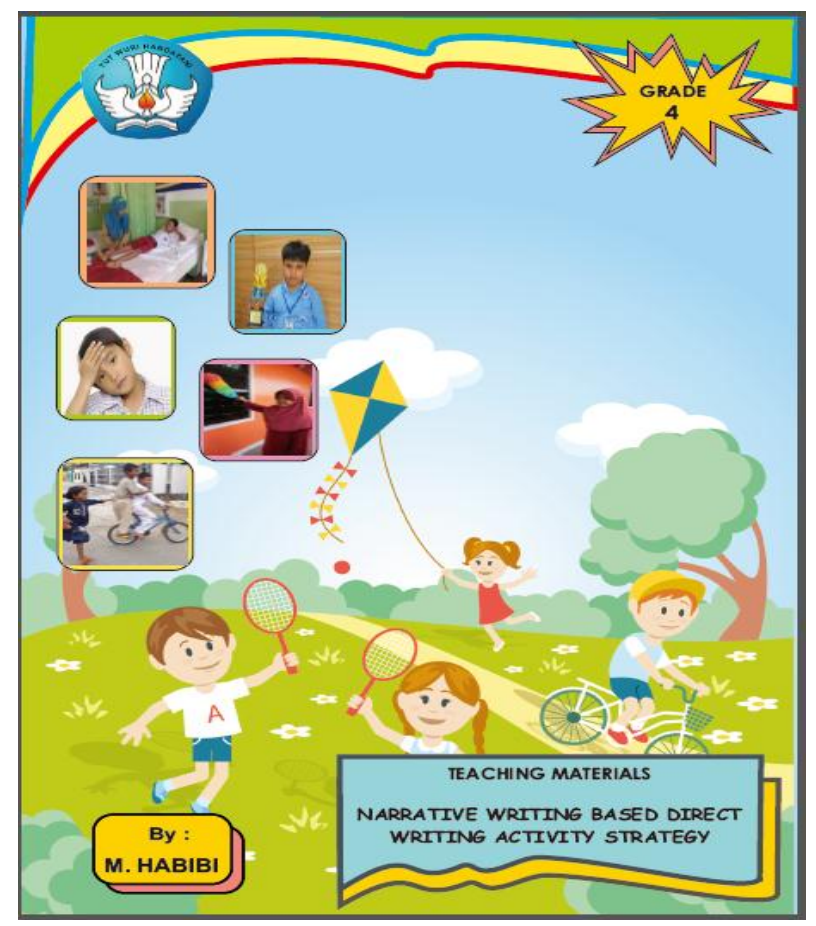

Figure 6. Desain of cover

\subsection{Development (Final Design and Data Validity)}

At the development stage, the design of the teaching material was finalized. At this stage, an instrument was also developed to assess the validity of the teaching material produced [49]. The instrument used is the work of researchers guided by the rules of the preparation of instrument validation. Validity is the level of suitability of the teaching material to be used in learning [27] writing narrative texts for the fourth grade students of elementary schools. Validity scores are obtained from expert and practitioner validator ratings for each aspect of the assessment determined. These aspects include: (1) content worthiness, (2) language use, (3) material presentation, and (4) graphic [45]. The value of the validity of the teaching material for each aspect of assessment can be seen in table 1 , while the overall level of validity of the teaching material can be seen in Figure 7. 
Table 1. Validation results of the teaching material for each aspect of assessment

\begin{tabular}{|c|c|c|c|c|c|c|c|c|}
\hline \multirow{2}{*}{ No } & \multirow{2}{*}{ Rated Aspect } & \multicolumn{6}{|c|}{ The Score of each aspect by the validator } & \multirow{2}{*}{ Average } \\
\hline & & V1 & $\mathrm{V} 2$ & V3 & P1 & P2 & P3 & \\
\hline A. & Content eligibility aspect & 3,87 & 3,63 & 4 & 3,75 & 3,75 & 4 & 3,83 \\
\hline B. & Language use aspect & 3,4 & 4 & 4 & 3,6 & 4 & 3,8 & 3,80 \\
\hline C. & Material presentation aspect & 3,5 & 3,67 & 3,83 & 3,67 & 3,67 & 3,83 & 3,70 \\
\hline D. & Graphic aspect. & 3,6 & 3,8 & 3,6 & 4 & 3,6 & 3,6 & 3,70 \\
\hline \multicolumn{8}{|c|}{ Overall average } & 3,76 \\
\hline
\end{tabular}

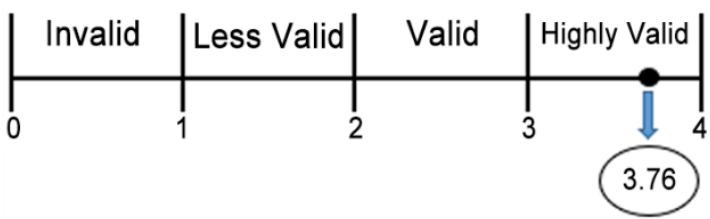

Figure 7. The level of validity of the teaching material developed

The mean of the validity of the teaching material developed was 3.76 with the highly valid category. The result of the validator's assessment indicates that: (1) the teaching material has contents that are in line with the substance of narrative writing learning material in elementary schools; (2) the teaching material use effective written language in accordance with good and correct Indonesian language rules; (3) the teaching material is presented systematically in the order of learning indicators and is equipped with explanatory information; (4) the teaching material has an attractive appearance, the use of varied colors and a proportional layout. From the results of this analysis it can be concluded that the narrative writing teaching material based on strategy direct writing activity is appropriate as a learning resource for narrative writing learning for elementary school students.

\subsection{Implementation}

The teaching material that had been declared valid was then tested on a specified research subject. This activity aims to obtain practicality data and data effectiveness of the teaching material.

\subsubsection{Practicality Data}

Practicality data is useful to find out the practicality of the teaching material when used in learning [25]. Through this data, it will be known whether the teaching material developed is practically used in teaching narrative writing for elementary school students. This data was obtained by: (1) observing the learning process of narrative writing using the narrative writing teaching material based on direct writing activity strategy, (2) asking for student responses and teacher responses as users of this teaching material. Observation of the learning process of narrative writing was done using an observation sheet. Student responses and teacher responses were collected using a questionnaire, where students and teachers were asked to give a score (1-4) for each question given. The results of observing the learning process of writing narratives using the teaching material developed can be seen in table 2 and figure 8 , while the calculation of the results of student responses and teacher responses can be seen in figure 9 and figure 10 .

Table 2. Observation result of the writing learning process

\begin{tabular}{cccc}
\hline \multirow{2}{*}{ Learning } & \multicolumn{2}{c}{ Expert Observation Result } & \multirow{2}{*}{ Average } \\
\cline { 2 - 3 } & $\mathrm{P} 1$ & $\mathrm{P} 2$ & \\
\hline 1 & 3,49 & 3,53 & 3,51 \\
\hline 2 & 3,61 & 3,61 & 3,61 \\
\hline 3 & 3,74 & 3,83 & 3,78 \\
\hline \multicolumn{3}{c}{ Overall Average } & 3,63 \\
\hline
\end{tabular}

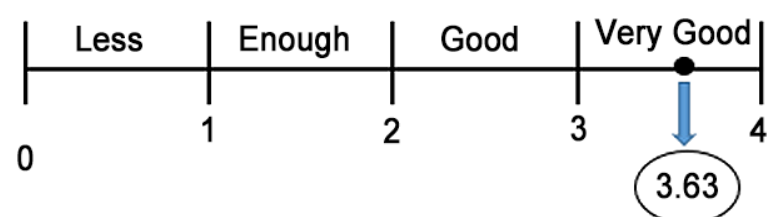

Figure 8. The level of success in implementing narrative writing learning

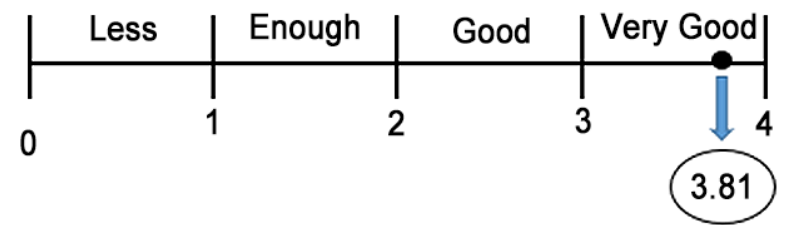

Figure 9. Result of students responses to the practicality of the teaching material

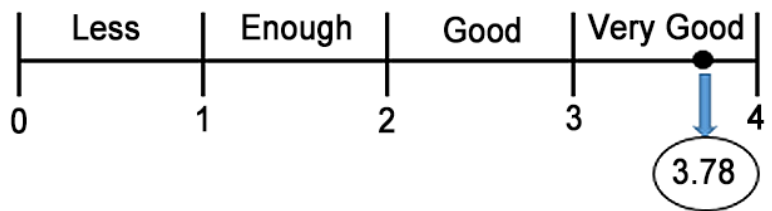

Figure 10. Result of teacher responses to the practicality of the teaching material

The value of the learning process of narrative writing according to table 2 and figure 8 was 3.63 with a very good 
category. This indicates that the learning process of narrative writing using the narrative writing teaching material based on direct writing activity strategy was carried out in a structured manner. Learning was carried out according to the stages of writing and stages of the direct writing activity strategy. Students were able to follow each of these stages well and could complete the writing assignments contained in the teaching material.

The result of student responses according to Figure 9 was 3.81 with very good criteria, meaning that teaching materials developed were very practical to use. Students felt motivated to write and felt helped during narrative writing activities. Students got new experiences in learning to write narration because the teaching material used was different from the previous one.

Meanwhile, the result of teacher responses according to Figure 10 was 3.78 with very good criteria. These results indicated that the teacher felt the teaching material developed was easy to apply in learning and greatly helped the teacher in teaching narrative writing skills to elementary school students

\subsubsection{Effectivity Data}

The effectivity data is needed to find out whether the developed teaching material can improve the learning outcomes of narrative writing of the fourth grade elementary school students. This data was obtained by comparing the scores of the narrative text of students in the experimental class (using the teaching material developed) against the scores of the narrative text of students of the control class (using teaching materials commonly used before). These data were then analyzed through statistical tests using the one-party t-test, namely the right hand (posttest) with a significant level of 0.05 . The testing criteria used the Independent Sample t-test by first ensuring that the pretest and posttest scores of the experimental class and the control class are normally distributed and homogeneous. t-test results on the scores of the results of the student narrative texts of the experimental class and the control class can be seen in the following figure.

\begin{tabular}{|c|c|c|c|c|c|c|c|c|c|c|}
\hline & \multicolumn{10}{|c|}{ Independent Sample Test } \\
\hline & & \multicolumn{3}{|c|}{$\begin{array}{l}\text { Levene's Test for } \\
\text { Equality of Variance }\end{array}$} & \multirow[b]{2}{*}{ df } & \multirow[b]{2}{*}{$\begin{array}{c}\text { Sig. } \\
\text { (2-tailed) }\end{array}$} & \multicolumn{2}{|c|}{$\begin{array}{l}\text { t-test for Equality } \\
\text { of Means }\end{array}$} & \multicolumn{2}{|c|}{$\begin{array}{l}95 \% \text { Confidence Interval } \\
\text { of the Difference }\end{array}$} \\
\hline & & $\mathrm{F}$ & Sig. & $\mathrm{t}$ & & & $\begin{array}{l}\text { Means } \\
\text { Difference }\end{array}$ & $\begin{array}{l}\text { Std. Error } \\
\text { Difference }\end{array}$ & $\begin{array}{l}\text { of the L } \\
\text { Lower }\end{array}$ & Upper \\
\hline Hasil & $\begin{array}{l}\text { Equal variances } \\
\text { assumed }\end{array}$ & .637 & .429 & 5.429 & 46 & .000 & 14.37500 & 2.64733 & 9.04539 & 19.70461 \\
\hline Belajar & $\begin{array}{c}\text { Equal variances not } \\
\text { assumed }\end{array}$ & & & 5.429 & 45.565 & .000 & 14.37500 & 2.64733 & 9.04402 & 19.70598 \\
\hline
\end{tabular}

Figure 11. T-test Results (independent Sample t-test) 


\section{Conclusions}

Based on the findings, it can be concluded that the teaching material developed has fulfilled the valid, practical, and effective criteria, and it can improve the learning outcomes of student narrative writing. The validation score by experts in education was 3.76 which shows that teaching material was very good and suitable for learning to write narrative text. The student response scores and the teacher responses as users of teaching materials were 3.81 and 3.78 with very good criteria that show that the teaching material was very practical to use in learning to write. $t$-test was used to test the effectiveness of the use of the teaching material. The result of the t-test showed $t_{\text {obs }}(5.43) \geq t_{\text {table }}$ (2.07), so it was concluded that $\mathrm{H} 0$ was rejected and teaching materials were proven to successfully improve student learning outcomes.

\section{REFERENCES}

[1] C. Lehmann, "Linguistic competence: Theory and empiry," Folia Linguist., vol. 41, no. 3-4, pp. 223-278, 2007, doi: 10.1515/flin.41.3-4.223.

[2] H. G. Tarigan, Menulis Sebagai Suatu Keterampilan Berbahasa (Writing as a language skill). Bandung: PT. Angkasa, 2008.

[3] R. Kurnia, D. Arief, and I. Irdamurni, "Development of Teaching Material for Narrative Writing Using Graphic Organizer Story Map in Elementary School," Int. J. Res. Couns. Educ., vol. 1, no. 1, p. 22, 2018, doi: 10.24036/009za0002.

[4] M. Şengül, "The Opinions of Instructors Teaching Turkish to Foreigners About the Writing Skills of Syrian Students," J. Educ. Train. Stud., vol. 3, no. 5, pp. 177-186, 2015, doi: 10.11114/jets.v3i5.928.

[5] I. M. Muslim, "Helping EFL Students Improve Their Writing," Int. J. Humanit. Soc. Sci., vol. 4, no. 2, pp. 105112,2014

[6] I. Jalaluddin, M. Md. Yunus, and H. Yamat, "The Effect of Teacher's Assistance on Malaysian Rural L Writing Self-efficacy: A Case Study," Adv. Lang. Lit. Stud., vol. 2, no. 1, pp. 81-91, 2011, doi: 10.7575/aiac.alls.v.2n.1p.81.

[7] J. Cole and J. Feng, "Effective Strategies for Improving Writing Skills of Elementary English Language Learners," in Chinese American Educational Research and Development Association Annual Conference, 2015, pp. 125.

[8] P. Bulut, "The Effect of Primary School Students' Writing Attitudes and Writing Self-Efficacy Beliefs on Their Summary Writing Achievement," Int. Electron. J. Elem. Educ., vol. 10, no. 2, pp. 281-285, 2017, doi: $10.26822 /$ iejee. 2017236123 .

[9] S. Despande, "Teaching Writing Skills in English: Involvement of Students in the Assessment and Correction of Their Own Errors," Int. J. English Lang. Teach., vol. 3, no. 1, pp. 68-73, 2014.

[10] S. Manik and J. D. Sinurat, "Improve Students' Narrative Writing Achievement Through Film at SMA Negeri 1 Palipi," Int. J. English Linguist., vol. 5, no. 2, pp. 172-173, 2015, doi: 10.5539/ijel.v5n2p172.

[11] A. Koura and F. Zahran, "Using Habits of Mind to Develop EFL Writing Skills and Autonomy," Arab World English J., vol. 8, no. 4, pp. 183-198, 2017, doi: 10.24093/awej/vol8no4.12.

[12] K. Anderson, M., \& Anderson, Text types in English 2. Australia: Macmillan, 1997.

[13] E. Grenner, V. Åkerlund, L. Asker-Árnason, J. van de Weijer, V. Johansson, and B. Sahlén, "Improving narrative writing skills through observational learning: a study of Swedish 5th-grade students," Educ. Rev., vol. 00, no. 00, pp. 1-20, 2018, doi: 10.1080/00131911.2018.1536035.

[14] F. Susilawati, "Teaching Writing of Narrative Text Through Digital Comic,” J. English Educ., vol. 5, no. 2, pp. 103-111, 2017.

[15] R. Wahyuningtyas, M. Maryaeni, and R. Roekhan, "Pengembangan Bahan Ajar Menulis Cerpen Dengan Konversi Teks Untuk Siswa Kelas VII SMP (Development of Short Story Writing Teaching Materials with Text Conversion for Grade VII Middle School Students)", J. Pendidik. - Teor. Penelitian, dan Pengemb., vol. 1, no. 7, pp. 1330-1336, 2016, doi: 10.17977/jp. v1i7.6562.

[16] S. . Slamet, Winarni, Retno, and Ismail, "The Development of Textbook for Study of Writing Poetry BasedCharacter in Contextual Learning," Int. Interdiscip. Res. J., vol. 6, no. 5, pp. 11-22, 2016.

[17] D. Aswita, S. Ramadhan, and T. Taufik, "Development of Teaching Material for Narrative Writing Using Graphic Organizer Type Circle Organizer in Elementary School," in International Conference on Language, Literature, and Education (ICLLE 2018), 2018, vol. 263, no. 4, pp. 250-254, doi: 10.2991/iclle-18.2018.42.

[18] N. Nurjani, "Pengembangan Bahan Ajar Menulis Narasi Berbasis Media Bagan Pohon Di Kelas V Sekolah Dasar (Development of Teaching Materials Narrative Writing Based on Tree Chart Media in Class V Elementary School)," Ta'dib, vol. 21, no. 1, p. 21, 2018, doi: 10.31958/jt.v21i1.1041.

[19] M. Zulela, Y. E. Y. Siregar, R. Rachmadtullah, and P. A. Warhdani, "Keterampilan Menulis Narasi Melalui Pendekatan Konstruktivisme di Sekolah Dasar (Narrative Writing Skills Through Constructivism Approaches in Primary Schools)," J. Pendidik. Dasar, vol. 8, no. 2, pp. 112-123, 2017, doi: 10.21009/JPD. 082.011.

[20] A. Kamariah, D. Husain, H. Atmowardoyo, and K. Salija, "Developing Authentic Based Instructional Materials for Writing Skill," J. Lang. Teach. Res., vol. 9, no. 3, p. 591, 2018, doi: 10.17507/j1tr.0903.19.

[21] A. Masood, "Exploiting Authentic Materials For Developing Writing Skills at Secondary Level," J. Lit. Lang. Linguist., vol. 1, no. 1, pp. 15-25, 2013.

[22] R. Eanes, Content Area Literacy. Teaching Today's and Tomorrow. New York: Delmar Publishers, 1997. 
[23] S. J. Crawley and Lee Mountain, Strategies for Guiding Content Reading (Second Edition). Allyn \& Bacon, 1995.

[24] S. Rietdijk, T. Janssen, D. van Weijen, H. van den Bergh, and G. Rijlaarsdam, "Improving writing in primary schools through a comprehensive writing program," J. Writ. Res., vol. 9, no. 2, pp. 173-225, 2017, doi: 10.17239/jowr-2017.09.02.04.

[25] E. H. Augusto-navarro, "The Design of Teaching Materials As a Tool in EFL Teacher Education : 2 . Choices in Teacher Education: Situated Practices," Ilha do Desterro; A J. English Lang. Lit. English Cult. Stud., vol. 68, no. 1, pp. 121-137, 2015, doi: http://dx.doi.org/10.5007/2175-8026.2 $015 \mathrm{v} 68 \mathrm{n} 1 \mathrm{p} 121$.

[26] S. Garton and K. Graves, Material in ELT: Current Issues. In International Perspectives Materials in ELT. Ontario, Canada: Palgrave Macmillan: 1-15, 2014.

[27] A. Aydin and C. Aytekin, "Teaching Materials Development and Meeting the Needs of the Subject: A Sample Application," Int. Educ. Stud., vol. 11, no. 8, p. 27, 2018, doi: 10.5539/ies.v11n8p27.

[28] Sujarno and A. Dian, "Development of Text Teaching Materials of Regional Learning Biography In Mathematics and Natural Science Students of State 5th School," IOSR J. Res. Method Educ., vol. 8, no. 5, pp. 35-39, 2018, doi: 10.9790/ 7388-0805033539.

[29] M. W. Kurniawati, S. Anitah, and S. Suharno, "Developing Learning Science Teaching Materials Based on Scientific to Improve Student Learning Outcome in Elementary School," Eur. J. Educ. Stud., vol. 3, no. 4, pp. 319-330, 2017, doi: 10.5281/zenodo.398991

[30] B. Tomlinson, "Materials Development for Language Learning and Teaching," Lang. Teach., vol. 45, no. 2, pp. 143-179, 2012, doi: 10.1017/S0261444811000528.

[31] A. S. Ahmar and A. Rahman, "Development of Teaching Material Using an Android," Glob. J. Eng. Educ., vol. 19, no. 1, pp. 72-76, 2017, doi: 10.26858/ gjeev19i1y2017p7376.

[32] S. Pinta Uli Br. Pasaribu, T. Asi Siburian, and A. Adisaputera, "The Development of Teaching Materials to Write Report Text Based on Inquiry," in 2nd Annual International Seminar on Transformative Education and Educational Leadership (AISTEEL 2017), 2017, vol. 104, no. 4, pp. 28-30, doi: 10.2991/aisteel-17.2017.7.

[33] F. Rokhman and Yuliati, "The Development of The Indonesian Teaching Material Based on Multicural Context by Using Sociolinguistic Approach at Junior High School," in Procedia - Social and Behavioral Sciences, 2010, vol. 9, pp. 1481-1488, doi: 10.1016/j.sbspro. 2010.12.353.

[34] L. G. Long and P. G. Higgins, "Successful Writing," Nurs. Manag., vol. 17, no. 11, p. 63???67, 1986, doi: 10.1097/00006247-198611000-00021.

[35] Y. N. Hellen and Muhd Al Hafizh, "Teaching Writing a Hortatory Exposition Text by Using," J. English Lang. Teach., vol. 3, no. September, p. 8, 2014.
[36] I. Sulistyo, "An Analysis of Generic Structure of Narrative Text," ETERNAL (English Teach. Journal), vol. 4, no. 2, pp. 169-181, 2013, doi: http://dx.doi.org/10.26877/eternal.v4i2.1956.

[37] V. K. T. Janne, F. Morken, W. A. Helland, and T. Helland, "The Dynamics of Narrative Writing in Primary Grade Children: Writing Process Factors Predict Story Quality," Read. Writing; An Interdiscip. J., vol. 29, no. 3, pp. 529-554, 2016, doi: 10.1007/s11145-015-9618-4.

[38] M. Habibi, C. Chandra, R. Mahyuddin, and S. Hendri, "Validity of Teaching Materials for Writing Poetry Based on Creative Techniques in Elementary Schools," Mimb. Sekol. Dasar, vol. 5, no. 3, pp. 145-154, Dec. 2018, doi: 10.17509/mimbar-sd.v5i3.14501.

[39] M. L. Syafii, "Improving the Quality in Writing Descriptive Texts of Madrasah Aliyah Students Through Directed Writing Activity Strategy," IDEAS J. English Lang. Teach. Learn. Linguist. Lit., vol. 7, no. 2, pp. 105-126, 2019, doi: 10.24256/ ideas.v7i2.1027.

[40] M. I. Sriyanto, Yesie Agustina, and Kartono, "Peningkatan Keterampilan Menulis Argumentasi Melalui Strategi DWA (Improving Argument Writing Skills Through Direct Writing Activity Strategy)," J. Didakt. Dwija Indria, vol. 2, no. 10 , pp. 1-6, 2014

[41] Borg \& Gall, Research Development. Boston: Allyn \& Bacon, 2007.

[42] M. Molenda, "In Search of The Elusive ADDIE Model," Perform. Improv., vol. 42, no. 5, pp. 40-42, 2015.

[43] A. B. Pribadi, Model Desain Sistem Pembelajaran (Learning System Design Model). Jakarta: Dian Rakyat, 2011.

[44] A. B. Pribadi, Desain dan Pengembangan Program Pelatihan Berbasis Kompetensi Implementasi Model ADDIE (Design and Development of Competency Based Training Programs for ADDIE Model Implementation). Jakarta: Kencana Prenada Media Group, 2016.

[45] Sugiyono, Metodologi Penelitian Kuantitatif, Kualitatif, dan $R \& D$ (Quantitative, Qualitative, and $R \& D$ Research Methodologies). Bandung: Alfabeta, 2016.

[46] H. Taherdoost, "Sampling Methods in Research Methodology; How to Choose a Sampling Technique for Research," Int. J. Acad. Res. Manag., vol. 5, no. 2, pp. 18-27, 2016, doi: 10.2139/ssrn.3205035.

[47] R. A. Johnson and D. W. Wichern, Applied Multivariate Statistical Analysis. New Jersey: Pearson Education, Inc, 2007.

[48] S. Kumar, P. Tutun Mukherjee, and S. Kumar RKGITW, "Teaching Materials and Teaching Aids-1 (Teaching Material) Paper 12; Module 24; E Text Principal Investigator Content writer: Content Reviewer," Amity Univ. $J$. , vol. 1 , no. 1 , p. $12,2017$.

[49] W. Lin, "Research on teaching materials management of track and field web course in college of physical education," Int. J. Emerg. Technol. Learn., vol. 11, no. 6, pp. 46-54, 2016, doi: 10.3991/ijet. v11i06.5460. 